Marquette University

e-Publications@Marquette

Exercise Science Faculty Research and Publications

Exercise Science, Department of

$11-1-2016$

\title{
The Relevance of Sex Differences in Performance Fatigability
}

Sandra K. Hunter

Marquette University, sandra.hunter@marquette.edu

Accepted version. Medicine \& Science in Sports \& Exercise, Vol. 48, No. 11 (November 2016):

2247-2256. DOI. (C) 2016 American College of Sports Medicine. Used with permission. 


\title{
The Relevance of Sex Differences in Performance Fatigability
}

\author{
Sandra K. Hunter \\ Exercise Science Program, Department of Physical Therapy, \\ Marquette University, \\ Milwaukee, WI
}

\begin{abstract}
Performance fatigability differs between men and women for a range of fatiguing tasks. Women are usually less fatigable than men, and this is most widely described for isometric fatiguing contractions and some dynamic tasks. The sex difference in fatigability is specific to the task demands so that one mechanism is not universal, including any sex differences in skeletal muscle physiology, muscle perfusion, and voluntary activation. However, there are substantial knowledge gaps about the task dependency of the sex differences in fatigability, the involved mechanisms, and the relevance to clinical populations and with advanced age. The knowledge gaps are in part due to the significant deficits in the number of women included in performance fatigability studies despite a gradual increase in the inclusion of women for the last $20 \mathrm{yr}$. Therefore, this review 1) provides a rationale for the limited knowledge about sex differences in performance fatigability, 2) summarizes the current knowledge on sex differences in fatigability and the potential mechanisms across a range of tasks, 3) highlights emerging areas of opportunity in clinical populations, and 4) suggests strategies to close the


knowledge gap and understanding the relevance of sex differences in performance fatigability. The limited understanding about sex differences in fatigability in healthy and clinical populations presents as a field ripe with opportunity for high-impact studies. Such studies will inform on the limitations of men and women during athletic endeavors, ergonomic tasks, and daily activities. Because fatigability is required for effective neuromuscular adaptation, sex differences in fatigability studies will also inform on optimal strategies for training and rehabilitation in both men and women.

Key Words: Sex Differences; Women; Muscle Fatigue

The limits of human performance during athletic events, ergonomic tasks, and daily activities are in part defined by fatigue that develops in the neuromuscular system in both men and women. This performance fatigability, commonly termed muscle fatigue, is an acute activity-induced reduction of force or power of a muscle; in the laboratory, it is typically quantified as the reduction in maximal strength or power, or the time to failure of a submaximal task. $\underline{20}$ The responsible mechanisms for performance fatigability range from the inadequate activation of the motor cortex and motoneuron pool to the altered cross-bridge kinetics within the activated muscle fibers. $\frac{53}{3}$ Performance fatigability and the involved mechanisms, however, can differ between men and women. Sex-based differences in anatomy and physiology can alter the rate and magnitude of fatigability that develops in the muscle and central nervous system for men compared with women. Although skeletal muscles of men are usually stronger and more powerful than women, men are often more fatigable than women for sustained or intermittent isometric contractions performed at a similar relative intensity (percentage of maximal strength). It is less clear whether these sex differences in fatigability occur during dynamic fatiguing tasks because the task variables are numerous, including the type, velocity, and intensity of the contractions, and the number of studies is limited. Defining and understanding these sexbased differences in fatigability are important 1) to understand the limits of performance in both men and women and 2) to determine optimal strategies for training and rehabilitation, which rely on fatigability to provide adequate neuromuscular overload and ultimately neuromuscular adaptation and increased strength or endurance. 
This review will 1) provide a rationale for the limited knowledge about sex differences in performance fatigability, 2) summarize the most up to date findings of sex differences in fatigability and the potential mechanisms across a range of tasks, 3) highlight emerging areas of opportunity in clinical populations, and 4) provide immediate and long-term strategies to close the knowledge gap in the understanding and the relevance of sex differences in performance fatigability.

\section{Setting The Record Straight: Numbers Matter}

Both past and recent studies of performance fatigability typically involve men, or often a lack of distinction between the sexes. This is also true, in general, across exercise science and biomedical research for human, animal, and basic cell studies. $\frac{5,66}{}$ Several key events during the last $25 \mathrm{yr}$ have increased awareness and promoted the involvement of women in biomedical research in the United States, and ultimately increased awareness of sex differences in performance fatigability. These events include the 1993 National Institutes of Health Revitalization Act mandating the inclusion of women in human studies (or the justification for lack of inclusion) and the 2001 Institute of Medicine report "Exploring the Biological Contributions of Sex". ${ }^{44}$ This report and subsequent commentaries ${ }^{65,66}$ serve as a reminder that every cell has a sex (defined by the chromosome complement of $X Y$ in women or $X X$ in men) that potentially influences function, and fatigability, in men and women differently. Furthermore, in 2015, the National Institutes of Health (NIH) announced a policy of including sex as a biological variable for research involving humans, animals, and cells (http://grants.nih.gov/grants/guide/notice-files/NOT-OD-15102.html). Although the NIH has made significant strides to include females in scientific studies, the inclusion of women in exercise physiology and performance studies remains inadequate.

One of the first reviews highlighting sex-based differences in fatigability was published in 2001 in Exercise and Sport Sciences Reviews. ${ }^{34}$ Since then, the number of studies determining whether there are sex differences in fatigability has increased, with several reviews emerging ${ }^{6,39-41}$ and culminating in a highlighted topic of interest at the World Congress of Exercise Fatigue in San Diego in May 2015. However, there is still a significant deficit in the numbers 
of women relative to men included in studies of performance fatigability (see Fig. 1A), despite improvements for the last $20 \mathrm{yr}$ (Fig. 1B).
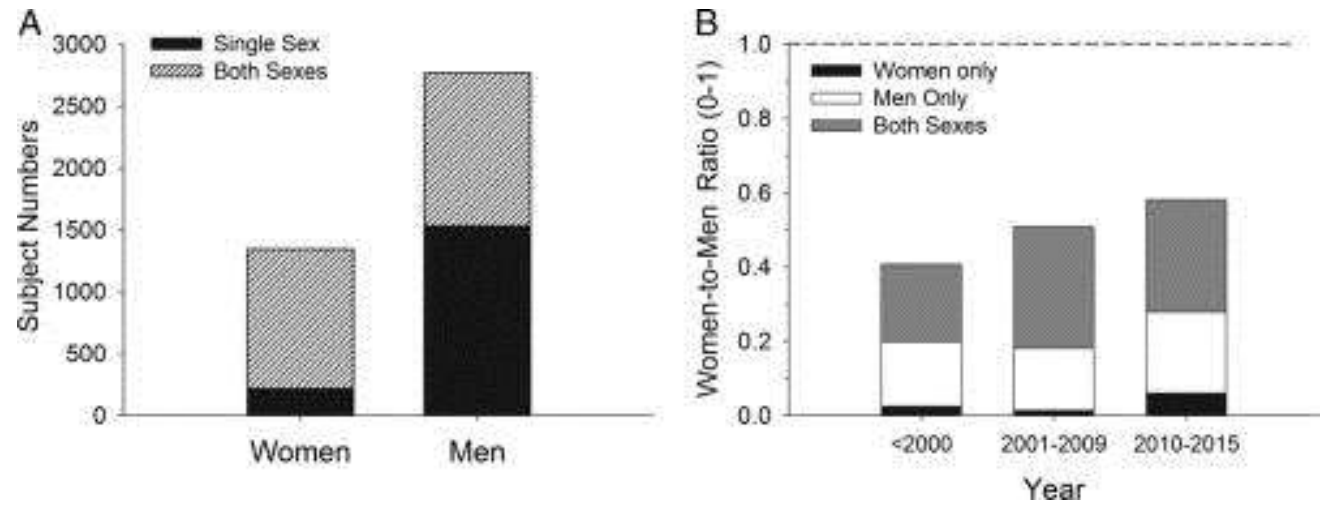

Figure 1. Numbers and ratio of men and women in 200 fatigability studies (19722015). A. Shown are the numbers of men and women reported in a sample of 200 studies ( $n=4113$ subjects total) published between 1972 and 2015 that assessed fatigability in humans. These human studies were sampled from several muscle fatigue reviews $\underline{2,19,53}$ and a literature search using an online data base (pubmed.org) to include data from more recent years. The vertical bar for each sex shows the number of men and women that were in a single sex study (black) or if both sexes were included in the study (hashed). B. Shown are the ratios of the numbers of women to men in the studies for those studies published in $<=2000,2001-2009$, and 2010-2015. A ratio of 1 is indicated by the dashed line and represents equal numbers of men and women. There is an increase in the number of women included in the studies relative to men, but there are still large deficits across all the years. Each vertical bar shows the proportion of the subjects represented in the vertical bar included in a study with women only (black), men only (white), or both sexes included (gray). Thus, the low ratio of women to men across the different years in the sample of 200 studies is largely attributed to a greater number of studies that include men only.

There are consequences to not including women in studies at the same rate as men. A disproportionate testing of men compared with women, and the underreporting of sex effects, can mask the magnitude of the sex differences in fatigability and performance. An example of how sampling bias can influence this magnitude is demonstrated with the marathon event. Historically, women were not permitted to competitively run the marathon until the 1970s. Since then, the number of female runners has increased in major marathons across all age-groups; the large initial increase in participation paralleled the improvement in world record times and the marked reduction in the sex difference of the fastest marathon 
times 46 to an $\sim 11 \%-12 \%$ difference between men and women for the last $20 \mathrm{yr} . \underline{48}$

However, among elite, lower placed, and older runners in the major world marathons, the sex difference is larger than can be explained by physiological differences between men and women. 47,48 The large sex difference in marathon performance was associated with lower participation rates among the women runners compared with the men runners. $\frac{47}{}$ The more equitable the numbers of men and women within an age-group, the closer the sex difference approached $11 \%-12 \%$. 47 This example highlights that the sex difference in performance due to physiological differences can be masked if the pool of men and women are not equitable in numbers, presumably in part, because of a reduced talent pool among the women. As a discipline, exercise science must make every effort to ensure an accurate understanding of the similarities and the differences in the performance and fatigability of both men and women; this can be accomplished by including more women in research studies.

\section{Current Knowledge On Sex Differences In Performance Fatigability}

In general, women are less fatigable than men for many isometric tasks and some dynamic tasks when young healthy men and women perform similar intensity contractions. $\underline{40}$ This section will summarize the main findings, emerging themes, and areas of opportunity.

\section{The Sex Difference in Fatigability Is Specific to the Task}

The dominant mechanism contributing to performance fatigability in both men and women is associated with the site in the neuromuscular system that is stressed the most, and this is determined by the demands of the task. $\underline{21}$ For a given fatiguing task, sex differences within the neuromuscular system can alter the rate at which a site is stressed for men compared with women, resulting in a sex difference in fatigability. $\underline{39}$ Thus, when task demands change for men and women, such as the intensity of isometric contraction or whether it is sustained or intermittent, the sex-based difference in fatigability can also change. Both task differences and potential mechanisms are discussed in the following sections. Including women

Medicine \& Science in Sports \& Exercise, Vol 48, No. 11 (November 2016): pg. 2247-2256. DOI. This article is @ American College of Sports Medicine and permission has been granted for this version to appear in e-Publications@Marquette. American College of Sports Medicine does not grant permission for this article to be further copied/distributed or hosted elsewhere without the express permission from American College of Sports Medicine. 
in a range of performance fatigability studies across different tasks will fill the knowledge gaps as to whether there are relevant sex differences across the many types of fatiguing tasks.

\section{Much of Our Current Knowledge and Understanding of Sex Differences in Fatigability Is Based on Isometric Contractions of a Single Limb}

Women are less fatigable than men during isometric fatiguing

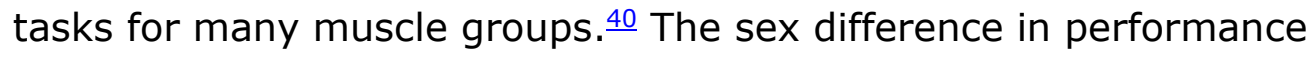
fatigability for isometric contractions, however, varies with the muscle group involved and the intensity of the contraction. ${ }^{39}$ Figure 2 illustrates that the sex difference in fatigability is less for the ankle dorsiflexor muscles than the elbow flexor muscles, $\frac{3}{3}$ with no sex difference reported for a low force sustained contraction with the elbow extensor muscles. $\frac{17}{}$ However, there are limited studies for several muscle groups, including the elbow extensor muscles and the plantar flexor muscles. Figure 2 also shows that, in general, for sustained isometric contractions, the sex difference in fatigability is less for sustained isometric contractions at high intensities compared with low-intensity sustained contractions. ${ }^{63,98}$ The varying sex differences in performance fatigability between muscle groups and for fatiguing contractions of different intensities (high vs low intensities) and contraction types (such as sustained vs intermittent) are examples of the task dependency of the sex difference in fatigability. 


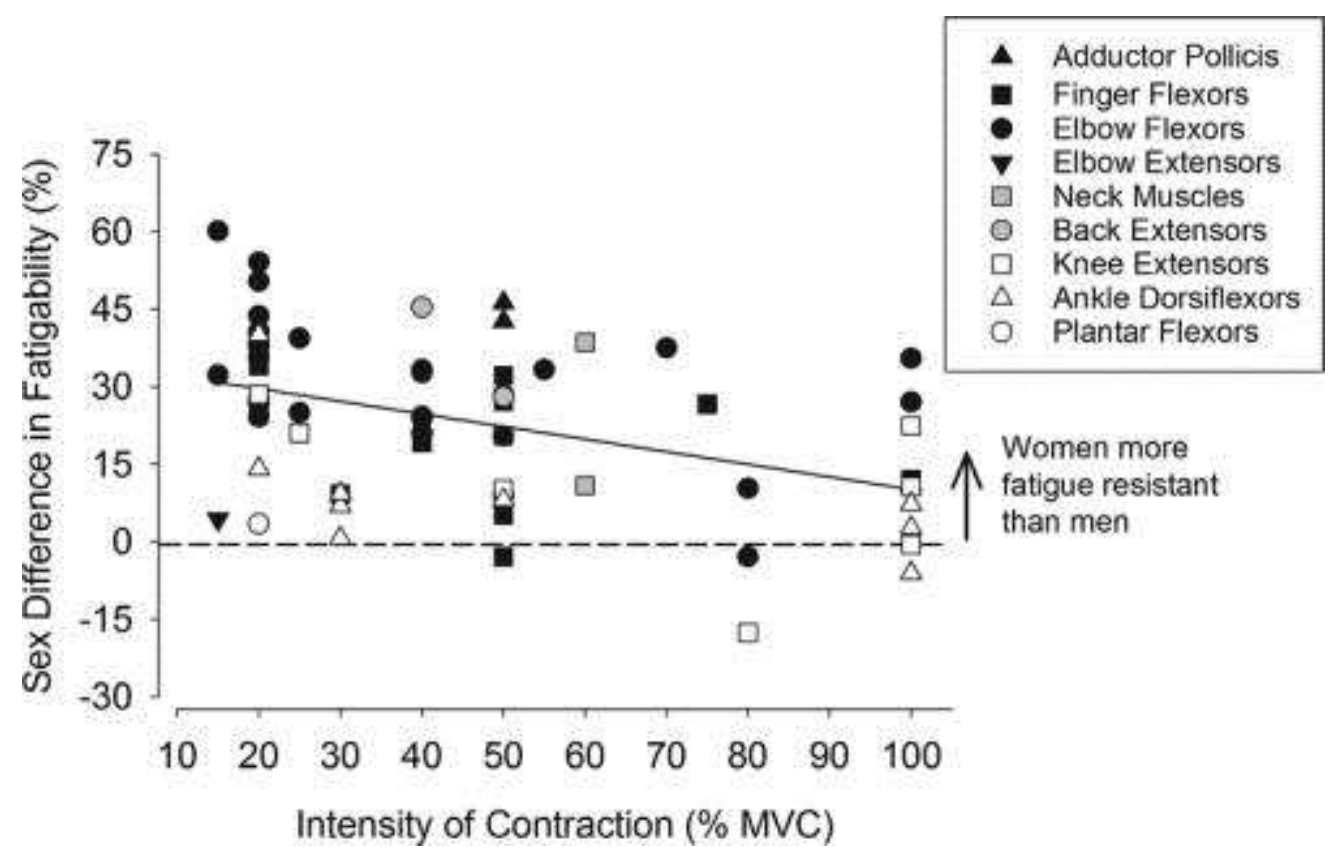

Figure 2. Sex differences in fatigability for voluntary isometric contractions. Represented are mean data from 46 isometric contraction studies (intermittent and sustained) published between 1975 and 2015 that assessed the fatigability of men and women. Plotted is the percentage sex difference in fatigability in each study, calculated as the mean difference in fatigability between the men and the women as a percent of the women's value. The fatigability values used for the calculation were either the fatigue index or the time to task failure for the sustained or intermittent isometric fatiguing contractions. The $x$-axis represents the contraction intensity (percentage of maximal voluntary contraction [MVC]) at which the fatiguing contractions were performed. Upper limb muscles are represented in closed symbols and lower limb muscles in open symbols. Back and neck muscles are represented as gray symbols. Most data points are above the line, indicating women were less fatigable than men for many of the muscle groups. There was a significant negative relation between the relative contraction intensity and the magnitude of the sex difference for the isometric contractions when all muscle groups were included $\left(r^{2}=\right.$ 0.19). Updated and adapted from Hunter. $\underline{40}$

\section{There Are Sex Differences in Fatigability for Some Dynamic Tasks with a Single Limb, but This Is not a Consistent Finding among the Limited Number of Studies}

In general, the sex difference in fatigability for dynamic tasks seems to be diminished relative to isometric contractions. $\underline{41}$ The dearth of studies contributes to the ambiguity as to whether sex differences exist. A tremendous opportunity exists to generate highimpact studies that determine the magnitude and mechanisms for sex differences in the performance fatigability of dynamic tasks.

Medicine \& Science in Sports \& Exercise, Vol 48, No. 11 (November 2016): pg. 2247-2256. DOI. This article is (C) American College of Sports Medicine and permission has been granted for this version to appear in e-Publications@Marquette. American College of Sports Medicine does not grant permission for this article to be further copied/distributed or hosted elsewhere without the express permission from American College of Sports Medicine. 
NOT THE PUBLISHED VERSION; this is the author's final, peer-reviewed manuscript. The published version may be accessed by following the link in the citation at the bottom of the page.

Summarized in the following sections are conclusions from recent studies that are reviewed more extensively elsewhere. $\underline{41}$

Shortening muscle activation

Women were less fatigable than men for some upper and lower limb muscles during shortening contractions in some studies, including the knee extensors, elbow flexor, and plantar flexor muscles, $\underline{33,63,70}$ but there was no sex difference in other studies (e.g., 15,83). Emerging evidence suggests that the sex difference is specific to the requirements of the dynamic task, including contraction velocity and intensity, and the muscle group involved during singlelimb exercise. $\frac{41}{}$ For example, women were less fatigable than men for a dynamic task with the elbow flexor muscles at slow but not high velocity contractions. $\frac{83,96}{}$ Contractile mechanisms were responsible for the sex difference in fatigability during the slow velocity contractions, with minimal sex differences in the reduction in voluntary activation when assessed with transcranial magnetic stimulation. $\underline{96}$ Comparison of these studies suggests the velocity of contraction with the elbow flexor muscles influences whether there is a sex difference in fatigability, with larger sex differences at slower contraction velocities.

Furthermore, for the knee extensor muscles, when fatigability was quantified as a reduction in the maximal voluntary isometric contraction (MVIC) force after a fast dynamic fatiguing task, women were less fatigable than men, despite a similar reduction in power for the 90 fast velocity contractions. $\frac{83}{}$ This is in contrast to the elbow flexor muscles tested in the same subjects and in the same study, $\underline{83}$ where there was no sex difference in the reduction in power or the reduction in MVIC. Thus, the contraction mode used to quantify performance fatigability during and after dynamic tasks in specific muscle groups will influence the observed sex difference in fatigability.

\section{Lengthening muscle activation}

Initial studies suggest that maximal force loss in response to repeated lengthening activation is either similar for men and women (e.g.,$\left.\frac{38,72,77}{}\right)$, or that women experience greater reductions in force than men (e.g.,$\frac{73,84}{}$ ). For example, there was a slower recovery in maximal force for women compared with men after repeated lengthening contractions with the ankle dorsiflexor muscles, and differences were associated with contractile mechanisms. $\underline{73}$

Medicine \& Science in Sports \& Exercise, Vol 48, No. 11 (November 2016): pg. 2247-2256. DOI. This article is @ American College of Sports Medicine and permission has been granted for this version to appear in e-Publications@Marquette. American College of Sports Medicine does not grant permission for this article to be further copied/distributed or hosted elsewhere without the express permission from American College of Sports Medicine. 
Lengthening activation is able to generate greater maximal torque than maximal isometric and shortening activations at the same velocity, but voluntary activation is usually less. $\frac{18}{} \mathrm{~A}$ complicating and cautionary note is that repeated lengthening activation will elicit muscle damage and delayed onset muscle soreness (DOMS). $\underline{16}$ Hence, delineating whether the reduction in force or power is due to fatigability or DOMS is challenging. Because fatiguing, lengthening contractions are important in optimizing muscle hypertrophy during strength training and rehabilitation programs, $\underline{79}$ addressing sex differences in fatigability may reveal information that is relevant to individualizing training programs in men and women.

\section{There Are Sex Differences for Sprint Exercise, but More Studies Are Needed to Bridge the Gap between Single- Limb and Whole-Body Performance}

The fatigability of single-limb muscle groups provides insight into the mechanisms for the differences in performance fatigability during exercise with multiple muscle groups. Consistent with the single-limb exercise, women exhibit less muscle fatigue during or after multiple sprint exercise,,$\underline{6}$ including cycling $\underline{7}$ and running. $\frac{58}{6}$ The sex differences in sprint exercise seem to be primarily due to contractile and metabolic differences between men and women ${ }^{6}$ and also related to maximal power or torque. $\underline{7}$ These studies suggest that the fatigability of skeletal muscle during high-intensity repeated sprints and the subsequent recovery can differ for men and women.

\section{Women Can Be Less Fatigable than Men after Long- Duration Endurance Exercise}

Several studies demonstrate that after long-duration cycling and running, reductions in maximal strength of lower limb muscles are less for women than men primarily because of muscular mechanisms. $\frac{30,31,90}{1 t}$ is not known if sex differences in performance fatigability exist across different modes of long-duration fatiguing exercise, nor the ultimate relevance to longer-term recovery from such events. More studies informing of potential sex differences and the involved mechanisms after long-duration exercise will provide information for best recovery strategies for men and women.

\section{Mechanisms for the Sex Differences in Fatigability}

Medicine \& Science in Sports \& Exercise, Vol 48, No. 11 (November 2016): pg. 2247-2256. DOI. This article is (C) American College of Sports Medicine and permission has been granted for this version to appear in e-Publications@Marquette. American College of Sports Medicine does not grant permission for this article to be further copied/distributed or hosted elsewhere without the express permission from American College of Sports Medicine. 
Contractile mechanisms play a primary role in the sex difference of fatigability (e.g., $\stackrel{42,95}{ }$ ), but other mechanisms, including muscle perfusion and voluntary activation, also dominate for some select tasks and muscle groups. For example, the sex difference in fatigability was attributable to a greater loss of voluntary activation for men compared with women during and after isometric fatiguing contractions with the lower limb muscles. $\frac{61,81}{1}$ The interaction of potential mechanisms is illustrated in Figure 3 and summarized in the next section, with more detailed explanations elsewhere. $\underline{40}$ Of note is the interconnectedness between the systems, making it difficult to tease apart the originating causes for the differences in fatigability between men and women. A key point, however, is that the dominant mechanism(s) for the sex difference in fatigability will change with the task demands. For example, the larger muscle mass and strength of men $\underline{64}$ can play a primary role in limiting blood flow more rapidly in men than women during low-to-moderate force sustained isometric contractions performed at the same relative intensity. $\stackrel{44}{ }$ Greater intramuscular pressures exerted onto the feed arteries can limit perfusion and oxygen supply, with an increased metabolite buildup in the men compared with the women. When the contraction is intermittent, the muscle is relatively perfused, $\underline{45}$ so other mechanisms are primarily responsible for the sex difference in fatigability. Other mechanisms may include sex differences in muscle metabolism and contractile function,,$\underline{6}$ voluntary activation, $\underline{61,81}$ and possibly differences in muscle perfusion in response to vasodilation and sympathetic activation ${ }^{45,50,68}$ (Fig. 3). 


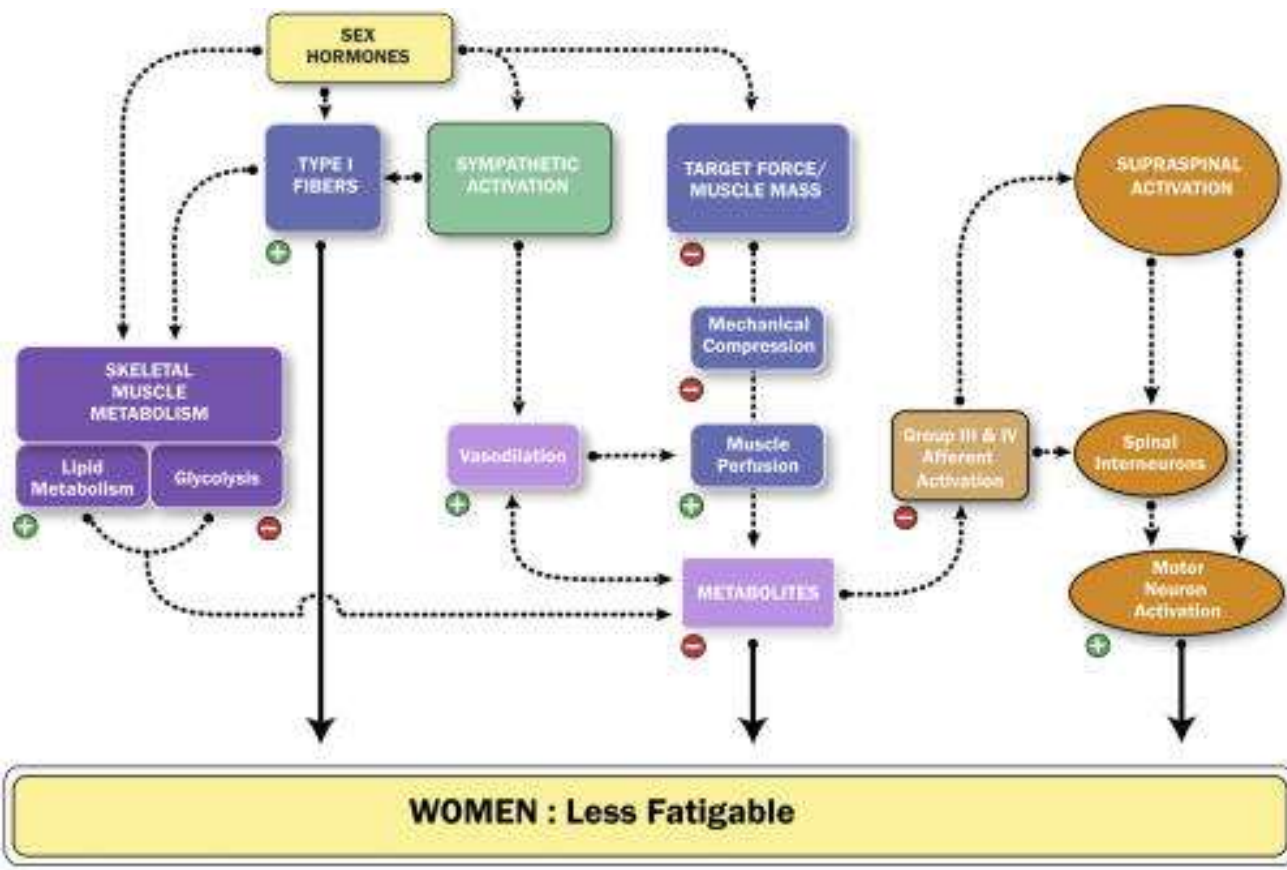

Less in women than in men

Q Greater in wamen than in men

Figure 3. Mechanisms for sex differences in fatigability. Shown are potential mechanisms that can contribute to women less fatigable than men during fatiguing contractions. The contribution of a potential mechanism will vary with the task conditions and demands so that one dominant mechanism is not universal to the sex difference in performance fatigability. A negative sign indicates that the physiological variable or process is less in women than men, and conversely, a positive sign indicates it is greater in women than men. Adapted from Hunter. $\underline{40}$

\section{Skeletal muscle physiology is a primary mechanism for observed sex differences in performance fatigability}

There are sex differences in whole-body substrate use during endurance exercise: women oxidize more fat and less carbohydrate and amino acids than men during similar intensity endurance exercise ${ }^{89}$ originating in part from sex differences within the skeletal muscle. $\underline{6}$ Men have greater glycolytic capacity than women, and women have greater oxidative capacity of whole muscle than men. ${ }^{23,82}$ This sex difference in whole-muscle energy metabolism is related to differences in the proportional area of type I fibers in the skeletal muscle (see Fig. 4). Although the relative (percentage) numbers of fiber types may not differ between men and women (e.g., $\frac{57,71}{}$ ), women have smaller type II fibers than men, so that the whole muscle of women has greater relative area that is type I fiber 
NOT THE PUBLISHED VERSION; this is the author's final, peer-reviewed manuscript. The published version may be accessed by following the link in the citation at the bottom of the page.

(Fig. 4). Such sex differences in fiber-type proportional area are consistent with slower contractile properties, such as slower rates of relaxation, and a more fatigue-resistant muscle. $\frac{42,95,96}{}$ At the wholemuscle level, contractile function may differ, but relative to fiber size, the peak force, power, and shortening velocity of individual muscle fiber types that have been chemically skinned do not seem to differ between men and women, $54,55,92$ although aging and disuse may change this more for women than men. $\frac{11}{11}$

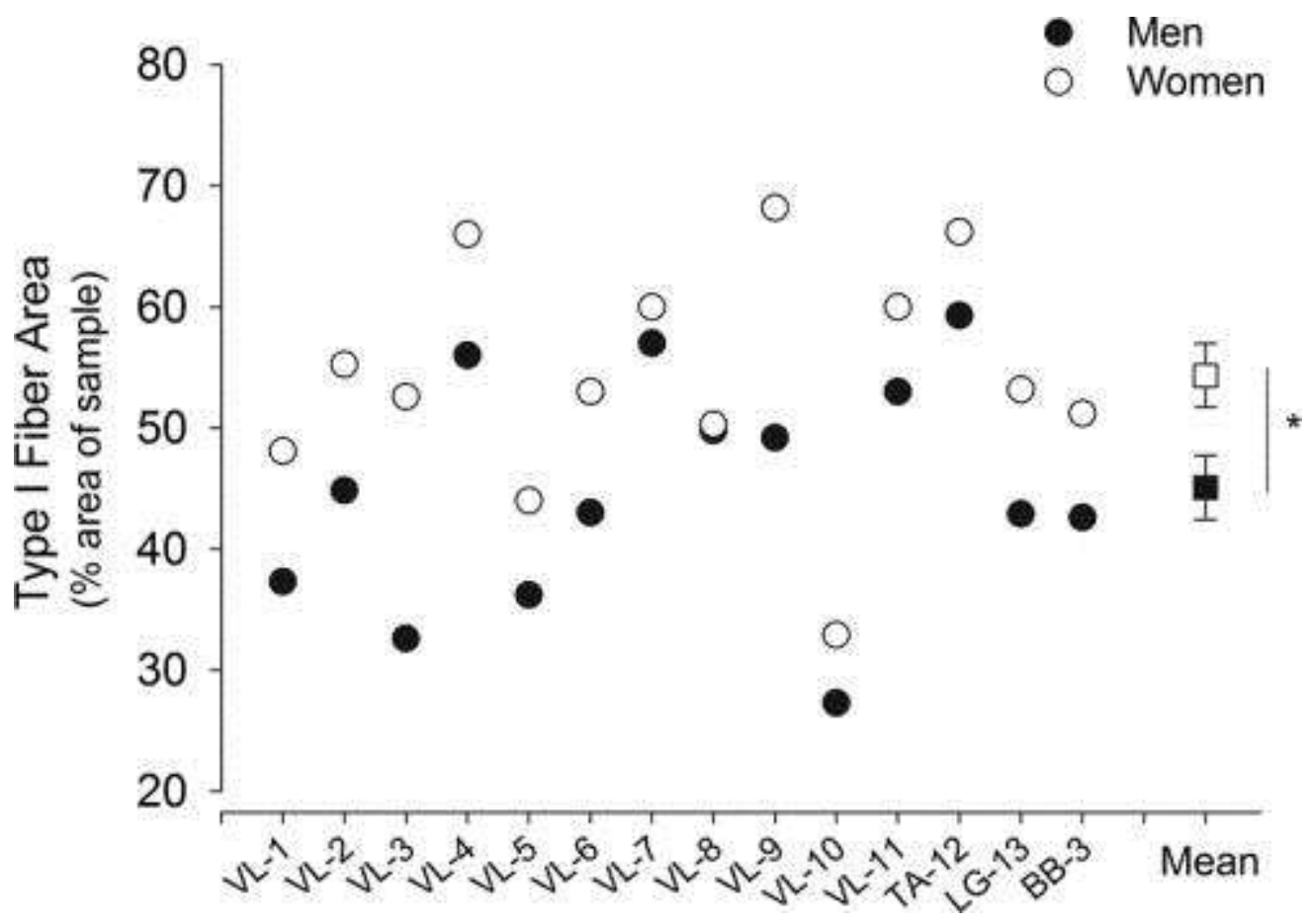

Figure 4. Type I fiber area (\%, proportional area of the sample) of skeletal muscle in men and women. The cross sections of muscle were histochemically analyzed for myosin ATPase activity from muscle biopsy samples of vastus lateralis (VL), tibialis anterior (TA), lateral gastrocnemius (LG), and biceps brachii (BB) of young men and young women who were sampled in the same study. All studies included biopsies of young adults with a mean age between 21 and $26 \mathrm{yr}$ for 12 of the 13 studies and 49

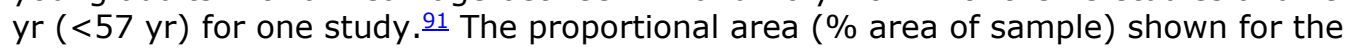
men and women in each study was calculated from the percentage number of fibers within a sample and the mean cross-sectional area of each fiber type within the sample. Thirteen studies are identified on the $x$-axis. These studies are coded by the muscle that was biopsied (VL, TA, LG, or BB) and a number that corresponds to the citation. The numbers of men and women biopsied in each study are also included, and this varied between 8 and 215 men or women. The mean \pm SEM proportional area of type I fibers of all the muscles from the 13 studies is plotted on the right side

Medicine \& Science in Sports \& Exercise, Vol 48, No. 11 (November 2016): pg. 2247-2256. DOI. This article is @ American College of Sports Medicine and permission has been granted for this version to appear in e-Publications@Marquette. American College of Sports Medicine does not grant permission for this article to be further copied/distributed or hosted elsewhere without the express permission from American College of Sports Medicine. 
NOT THE PUBLISHED VERSION; this is the author's final, peer-reviewed manuscript. The published version may be accessed by following the link in the citation at the bottom of the page.

of the figure. Women had greater type I fiber area (\%) than men for the 13 studies when pooled $(P<0.05)$. This graph was adapted and updated from data previously published. $40 \mathrm{VL}-1: 8637$ men and 38 women ( 26 and $25 \mathrm{yr}$, respectively). VL-2: $: 55215$ men and 203 women ( 24 and $23 \mathrm{yr}$ ). VL-3 and BB-3: $\underline{64} 8$ men and 8 women ( 23 and $25 \mathrm{yr}$ ). VL-4: $\underline{25} 20$ men and 19 women ( 25 and $23 \mathrm{yr}$ ). VL-5: $\frac{88}{95}$ men and 55 women ( 22 and $21 \mathrm{yr}$ ). VL-6: $\underline{12} 8$ men and 8 women ( 22 and $22 \mathrm{yr})$. VL-7: and 8 women ( 25 and $23 \mathrm{yr}$ ). VL-8: 1122 men and 18 women ( $49 \mathrm{yr}$ and $26-57 \mathrm{yr}$ ). VL-9: $\underline{78} 8$ men and 9 women ( 25 and $24 \mathrm{yr}$ ). VL-10: $\underline{60} 12$ men and 12 women ( 21 and $22 \mathrm{yr}$ ). VL-11: 229 men and 8 women ( 26 and $25 \mathrm{yr}$ ). TA-12:피 15 men and 15 women ( 26 and $23 \mathrm{yr}$ ). LG-13:프 9 men and 43 women ( 27 and $23 \mathrm{yr}$ ).

\section{Voluntary activation can explain some of the sex differences in performance fatigability}

Voluntary activation or neural drive is reduced during fatiguing exercise. Although men and women usually have similar voluntary activation when measured with evoked contractions (with either motor nerve or cortical stimulation) during maximal efforts at the start of exercise, 42,51 the reduction can vary between the sexes. In lower limb muscles, for example, reductions in voluntary activation can be greater in men than women at the end of isometric fatiguing

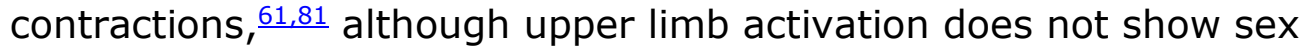
differences. $\frac{42,51,98}{1}$ The greater loss of neural drive in men during these high-intensity contractions of the lower limb are probably due to the larger accumulation of metabolites in the active skeletal muscle ${ }^{81}$ and the subsequent inhibitory feedback of the motoneuron pool from the group III and group IV sensory neurons. $\frac{62}{}$ More studies that include women are required to show the relevance of these inhibitory pathways to the sex differences in fatigability.

During fatiguing contractions, the importance of the cortex in limiting performance of men and women was highlighted with experiments that involved imposing a difficult cognitive challenge while the participant sustained a submaximal fatiguing contraction. $\frac{52,97}{}$ Both old and young women had greater increases in fatigability than men when the cognitive challenge (counting backwards by a two-digit number) was imposed during an isometric fatiguing contraction sustained at $20 \%$ MVIC with the elbow flexor muscles. $\frac{52,69}{}$ Certainly, there are widespread sex differences in brain activation 10 during cognitive tasks with some, but minimal, differences during motor tasks. $\underline{99}$ The mechanisms involved for the greater changes in the fatigability of the women than the men are not fully understood but involve a strength-related mechanism, possibly

Medicine \& Science in Sports \& Exercise, Vol 48, No. 11 (November 2016): pg. 2247-2256. DOI. This article is @ American College of Sports Medicine and permission has been granted for this version to appear in e-Publications@Marquette. American College of Sports Medicine does not grant permission for this article to be further copied/distributed or hosted elsewhere without the express permission from American College of Sports Medicine. 
involving muscle perfusion and relevant to the elbow flexor muscles. $\frac{52,93}{}$ Thus, when a cognitive challenge is imposed during an upper limb fatiguing contraction, the strength of the contributing mechanism(s) to the sex difference in fatigability is altered (Fig. 3 ). Further studies are needed to determine the involved mechanisms for the altered sex difference in fatigability when a cognitive challenge is imposed during a fatiguing motor task.

\section{Variance in Performance Fatigability across the Menstrual Cycle among Women Is Small Relative to the Differences between Men and Women}

On the basis of well-controlled studies, there are minimal differences in fatigability and contractile function across the different phases of the menstrual cycle in women at moderate environmental temperatures. $\underline{49}$ We have repeatedly found no association between the day of menstrual cycle and strength or fatigability of isometric fatiguing contractions (e.g.,,$\frac{43,51}{}$ ). Although there seem to be differences across the menstrual cycle in muscle sympathetic activity $\underline{26}$ and whole-body substrate use during endurance exercise, $\underline{89}$ fluctuations in the physiology, hormones, and performance are small compared with the larger differences between men and women. $\frac{89}{}$ This is also the case in animal experiments where the variance in physiology across the estrous cycle is small, with minimal differences in the variability of behavioral or physiological measures between male and female mice ${ }^{74}$ or rats. ${ }^{4}$ Thus, the larger differences between men and women seem to have greater effects on fatigability than across the menstrual cycle in premenopausal women. Further, the hormonal reductions across the lifespan may have greater effects on fatigability and function than across the menstrual cycle, and this is considered next.

\section{The Sex Difference in Fatigability Changes with Advanced Aging}

The sex difference in performance fatigability with advanced age is generally reduced $\underline{39}$ but not completely diminished. $\frac{14}{}$ The role of the hormonal reductions post menopause in women is not entirely clear. There are possible anticatabolic effects of hormone replacement therapy on skeletal muscle in older women and men (e.g.,$\frac{75,80}{}$ ), but there are limited studies and evidence for any effects of hormone 
replacement therapy on fatigability in men and women. ${ }^{13,28}$ Welldesigned human studies are needed to clarify the effects of the agerelated reduction in reproductive hormones on performance fatigability and the impact of hormone replacement therapy for both men and women.

Recovery from Fatiguing Exercise in Men and Women Is Not Well Explored

Significant sex differences in function and performance can be observed during recovery from a fatiguing bout of exercise, even when there may be no sex difference in the fatiguing exercise performance (1). For example, men showed greater reductions in MVIC force after a fatiguing bout of dynamic contractions when there was no sex difference in the reduction in power during the fatiguing task with the knee extensor muscles. $\frac{83}{}$ The mechanisms for the recovery of strength after a fatiguing bout of exercise may differ for men and women, but more studies are required to understand acute and long-term recovery in men and women and the contributing mechanisms.

\section{Sex Differences In Fatigability Among Clinical Populations}

Exciting opportunities exist for discovering whether there are sex differences in performance fatigability among clinical populations, especially if there is a greater prevalence of the disease/disorder in one of the sexes. Fatigability can limit exercise performance, ergonomic tasks, and daily activities, more so in older adults, those with chronic disease or disability such as stroke and multiple sclerosis (e.g., $\stackrel{56,87}{ }$ ). However, whether the sex differences in fatigability observed in healthy people are relevant to clinical populations is relatively unexplored, with some evidence for differences in people with multiples sclerosis and stroke. For example, the mechanisms contributing to sex differences in fatigability in healthy men and women differed in people with multiple sclerosis. $\frac{87}{}$ Furthermore, after stroke, men seem to have greater fatigability relative to age matched healthy people ( $45 \%$ difference), and also compared with women (14\% difference) (Kirking, Hunter, and Hyngstrom, unpublished data). 
Conversely, fatiguing contractions are the foundation of effective strength training and rehabilitation. Thus, understanding the mechanisms of fatigability for a range of tasks and muscle groups in both men and women will inform best strategies and practices for strength training and rehabilitation in clinical populations. In optimal doses followed by adequate recovery, fatigability over a number of sessions results in overload and adaptation of the neuromuscular system. Adaptations include optimizing neural activation and muscle hypertrophy, which result in increased strength and endurance. $\frac{9,67}{}$ Such adaptations are associated with increased performance, even for simple daily tasks such as rising from a chair in weak and clinical populations, especially in women. $\underline{27}$

There is also a tremendous potential for appropriately prescribed fatiguing contractions to help manipulate acute pain relief in clinical populations, particularly women. In young healthy adults, women report greater intensity and a sooner onset of pain than men in response to a painful stimuli. $\underline{76}$ Paradoxically, fatiguing exercise can temporarily offset pain (exercise-induced hypoalgesia). $\frac{36,59}{3}$ Thus, fatiguing exercise may be a viable treatment option to relieve pain acutely, and possibly long term, in response to exercise programs. These strategies could be used very effectively among women who experience greater prevalence for some pain conditions, such as fibromyalgia $\frac{35,37}{}$ and osteoarthritis. $\underline{8}$

\section{Increasing An Understanding Of Sex Differences In Performance Fatigability}

The sex bias in studies on performance fatigability has created a field that is ripe with opportunities. The following are strategies for investigators that will help clarify and progress the current knowledge and understanding of sex differences in performance fatigability, the dominant mechanisms, and the relevance to real-world activities.

\section{Reanalysis of existing data}

There are existing studies and data sets on performance fatigability that include both men and women but have not been analyzed for sex differences. The following are examples of two data sets, one that was analyzed for sex differences after the original data set was published (example 1) and one that was analyzed for sex 
differences after data collection was complete but not yet published (example 2).

Example 1: Figure 6 from Hunter and Enoka (2001) 44 shows data that were reanalyzed for sex differences from a study that had originally tested the fatigability of the first dorsal interosseous (FDI) across different contraction intensities. $\underline{29}$ The reanalysis of the FDI data ${ }^{29}$ provided evidence that, unlike the elbow flexor muscles, there were no sex differences in the fatigability of the sustained contractions with the FDI. However, similar to what had been seen in the elbow flexor muscles,, 4 the time to task failure was dependent on the absolute strength.

Example 2: The main aim of the study in this example ${ }^{32}$ was to investigate the effects of high-intensity exercise and sprint training on skeletal muscle $\mathrm{Ca}^{2+}$ regulation of the sarcoplasmic reticulum among men and women with type 1 diabetes ( $\mathrm{n}=8,3$ females and 5 males) and matched nondiabetic controls ( $n=8,3$ females and 5 males). $\mathrm{Ca}^{2+}$ regulation (sarcoplasmic reticulum $\mathrm{Ca}^{2+}$ uptake and $\mathrm{Ca}^{2+}$ ATPase activity) was determined from the homogenate of muscle biopsy samples of the vastus lateralis. $\underline{32}$ The original hypothesis, therefore, did not include analysis for sex differences, and so this was conducted after data collection was complete but before the data were published. Subsequent analysis showed that the difference in sarcoplasmic reticulum $\mathrm{Ca}^{2+}$ regulation between men and women was much greater than the acute effects of high-intensity exercise and sprint training in those with and without type 1 diabetes. Thus, it is possible that there are many existing data sets that are adequately powered and have potential sex differences but are not yet analyzed for the differences between men and women.

\section{Single sex studies named}

There are legitimate reasons for single sex studies. For these publications, a strong recommendation is to indicate the sex of the cohort preferably in the title with "... in men" or "... in women," and also in the abstract. In many single sex publications, the sex of the subjects is not immediately apparent, with an underlying assumption that the findings are relevant to both sexes. Naming the sex of the subjects up front in single sex studies will help the reader clarify the relevance of the results and conclusions to both sexes. 


\section{Include sex as study variable and include both men and women in a study}

Test enough men and women to determine whether sex differences exist or not. This is an obvious suggestion, but for many laboratories, it simply does not occur, sometimes for practical reasons but also because of the uncertainty of the possible confounding effects of the menstrual cycle in women. Two approaches to deal with this are to either control the time at which all women are tested within their menstrual cycle or simply to record the day of the cycle and determine retrospectively if there are associations between day or phase of the cycle. The earlier section on the variance in performance fatigability across the menstrual cycle among women suggests that the differences are probably small relative to the differences between men and women.

\section{Conduct studies to bridge the knowledge gap between the sex difference of fatigability and real-world activities in healthy and clinical populations}

Both men and women perform ergonomic tasks in the real world that are limited by fatigability. $\frac{100}{}$ This is especially true among clinical populations. $\underline{56}$ Determining the relevance of the laboratorybased tasks and fatigability that limit both sexes in ergonomic tasks and daily activities will provide insight to offset potential injury and disorder in men and women. Opportunities abound.

\section{Conclusions}

Sex differences in physiology and anatomy can have some profound differences on the body's response to performance fatigability that is specific to the task demands in healthy and clinical populations. Fatigability not only limits athletic performance and daily tasks in some populations but is also the foundation for neuromuscular adaptation needed for effective training and rehabilitation. Thus, in an era of greater individualized medicine and rehabilitation after injury and in response to training, one of the most basic variants to consider is the sex of the individual. In healthy young adults, sex differences in performance fatigability are often observed during sustained and intermittent single-limb isometric and in some dynamic tasks. The sex difference in fatigability is dependent

Medicine \& Science in Sports \& Exercise, Vol 48, No. 11 (November 2016): pg. 2247-2256. DOI. This article is @ American College of Sports Medicine and permission has been granted for this version to appear in e-Publications@Marquette. American College of Sports Medicine does not grant permission for this article to be further copied/distributed or hosted elsewhere without the express permission from American College of Sports Medicine. 
on the task demands so that one mechanism is not universal. Although contractile and metabolic mechanisms are often associated with the greater fatigue resistance of women compared with men for a range of tasks, there are also interactions with other mechanisms, including muscle perfusion and voluntary activation. Whether sex differences in fatigability are present and relevant among people with disability and chronic disease is largely unknown. Several basic strategies such as including sex as a study variable, and simply naming single sex studies in a title and abstract, can be adopted by investigators to increase the knowledge base and to understand the relevance of performance fatigability in men and women. The limited knowledge of the sex differences in fatigability in healthy and clinical population presents as a field ripe with opportunity for high-impact studies.

This work was in part supported by the National Institute of Aging (grant no. R21AG045766).

The author declares no conflicts of interest.

The American College of Sports Medicine is unable to endorse either the data or its interpretation, as presented in this article.

\section{References}

${ }^{1}$ Albert WJ, Wrigley AT, McLean RB, Sleivert GG. Sex differences in the rate of fatigue development and recovery. Dyn Med. 2006;5:2.

2 Amann M, Sidhu SK, Weavil JC, Mangum TS, Venturelli M. Autonomic responses to exercise: group III/IV muscle afferents and fatigue. Auton Neurosci. 2015;188:19-23.

${ }^{3}$ Avin KG, Naughton MR, Ford BW, et al. Sex differences in fatigue resistance are muscle group dependent. Med Sci Sports Exerc. 2010;42(10):1943-50.

${ }^{4}$ Becker JB, Prendergast JW, Liang BJ. Female rats are not more variable than male rats: a meta-analysis of neuroscience studies. Biol Sex Differ. $2016 ; 7: 34$.

${ }^{5}$ Beery AK, Zucker I. Sex bias in neuroscience and biomedical research. Neurosci Biobehav Rev. 2011;35(3):565-72.

${ }^{6}$ Billaut F, Bishop D. Muscle fatigue in males and females during multiplesprint exercise. Sports Med. 2009;39(4):257-78.

7 Billaut F, Bishop DJ. Mechanical work accounts for sex differences in fatigue during repeated sprints. Eur J Appl Physiol. 2012;112(4):1429-36

Medicine \& Science in Sports \& Exercise, Vol 48, No. 11 (November 2016): pg. 2247-2256. DOI. This article is @ American College of Sports Medicine and permission has been granted for this version to appear in e-Publications@Marquette. American College of Sports Medicine does not grant permission for this article to be further copied/distributed or hosted elsewhere without the express permission from American College of Sports Medicine. 
NOT THE PUBLISHED VERSION; this is the author's final, peer-reviewed manuscript. The published version may be

accessed by following the link in the citation at the bottom of the page.

${ }^{8}$ Boyan BD, Tosi LL, Coutts RD, et al. Addressing the gaps: sex differences in osteoarthritis of the knee. Biol Sex Differ. 2013;4(1):4.

9 Burd NA, Andrews RJ, West DW, et al. Muscle time under tension during resistance exercise stimulates differential muscle protein subfractional synthetic responses in men. J Physiol. 2012;590(Pt 2):35162.

${ }^{10}$ Cahill L. A half-truth is a whole lie: on the necessity of investigating sex influences on the brain. Endocrinology. 2012;153(6):2541-3.

${ }^{11}$ Callahan DM, Miller MS, Sweeny AP, et al. Muscle disuse alters skeletal muscle contractile function at the molecular and cellular levels in older adult humans in a sex-specific manner. J Physiol. 2014;592(Pt 20):4555-73.

12 Carter SL, Rennie CD, Hamilton SJ. Tarnopolsky. Changes in skeletal muscle in males and females following endurance training. Can J Physiol Pharmacol. 2001;79(5):386-92.

${ }^{13}$ Cheng A, Ditor DS, Hicks AL. A comparison of adductor pollicis fatigue in older men and women. Can J Physiol Pharmacol. 2003;81(9):873-9.

${ }^{14}$ Christie A, Snook EM, Kent-Braun JA. Systematic review and metaanalysis of skeletal muscle fatigue in old age. Med Sci Sports Exerc. 2011;43(4):568-77.

${ }^{15}$ Clark BC, Manini TM, The DJ, Doldo NA, Ploutz-Snyder LL. Gender differences in skeletal muscle fatigability are related to contraction type and EMG spectral compression. J Appl Physiol (1985). 2003;94(6):2263-72.

${ }^{16}$ Clarkson PM, Hubal MJ. Exercise-induced muscle damage in humans. Am J Phys Med Rehabil. 2002;81(11 Suppl):S52-69.

17 Dearth DJ, Umbel J, Hoffman RL, Russ DW, Wilson TE, Clark BC. Men and women exhibit a similar time to task failure for a sustained, submaximal elbow extensor contraction. Eur J Appl Physiol. 2010;108(6):1089-98.

18 Duchateau J, Baudry S. Insights into the neural control of eccentric contractions. J Appl Physiol (1985). 2014;116(11):1418-25

19 Enoka RM, Duchateau J. Muscle fatigue: what, why and how it influences muscle function. J Physiol. 2008;586(1):11-23.

${ }^{20}$ Enoka RM, Duchateau J. Translating fatigue to human performance. Med Sci Sports Exerc. 2016;48(11):2228-39.

${ }^{21}$ Enoka RM, Stuart DG. Neurobiology of muscle fatigue. J Appl Physiol (1985). 1992;72(5):1631-48.

Medicine \& Science in Sports \& Exercise, Vol 48, No. 11 (November 2016): pg. 2247-2256. DOI. This article is @ American College of Sports Medicine and permission has been granted for this version to appear in e-Publications@Marquette. American College of Sports Medicine does not grant permission for this article to be further copied/distributed or hosted elsewhere without the express permission from American College of Sports Medicine. 
NOT THE PUBLISHED VERSION; this is the author's final, peer-reviewed manuscript. The published version may be accessed by following the link in the citation at the bottom of the page.

22 Esbjornsson M, Rundqvist HC, Mascher $\mathrm{H}$, et al. Sprint exercise enhances skeletal muscle p70S6k phosphorylation and more so in women than in men. Acta Physiol (Oxf). 2012;205(3):411-22.

${ }^{23}$ Esbjornsson M, Sylven C, Holm I, Jansson E. Fast twitch fibres may predict anaerobic performance in both females and males. Int J Sports Med. $1993 ; 14(5): 257-63$.

${ }^{24}$ EsbjornssonLiljedahl M, Bodin K, Jansson E. Smaller muscle ATP reduction in women than in men by repeated bouts of sprint exercise. J Appl Physiol. 2002;93(3):1075-83.

${ }^{25}$ EsbjornssonLiljedahl M, Sundberg CJ, Norman B, Jansson E. Metabolic response in type I and type II muscle fibers during a 30-s cycle sprint in men and women. J Appl Physiol (1985). 1999;87(4):1326-32.

${ }^{26}$ Ettinger SM, Silber DH, Gray KS, et al. Effects of the ovarian cycle on sympathetic neural outflow during static exercise. J Appl Physiol (1985). 1998;85(6):2075-81.

27 Fiatarone MA, O'Neill EF, Ryan ND, et al. Exercise training and nutritional supplementation for physical frailty in very elderly people. $\mathrm{N}$ Engl J Med. $1994 ; 330(25): 1769-75$.

${ }^{28}$ Finni T, Noorkoiv M, Pollanen E, et al. Muscle function in monozygotic female twin pairs discordant for hormone replacement therapy. Muscle Nerve. 2011;44(5):769-75

${ }^{29}$ Fuglevand AJ, Zackowski KM, Huey KA, Enoka RM. Impairment of neuromuscular propagation during human fatiguing contractions at submaximal forces. J Physiol. 1993;460:549-72.

30 Glace BW, Kremenic IJ, McHugh MP. Sex differences in central and peripheral mechanisms of fatigue in cyclists. Eur J Appl Physiol. 2013;113(4):1091-8.

${ }^{31}$ Glace BW, McHugh MP, Gleim GW. Effects of a 2-hour run on metabolic economy and lower extremity strength in men and women. J Orthop Sports Phys Ther. 1998;27(3):189-96.

32 Harmer AR, Ruell PA, Hunter SK, et al. Effects of type 1 diabetes, sprint training and sex on skeletal muscle sarcoplasmic reticulum $\mathrm{Ca}^{2+}$ uptake and $\mathrm{Ca}^{2+}$-ATPase activity. J Physiol. 2014;592:523-35.

${ }^{33}$ Hebert-Losier K, Holmberg HC. Dynamometric indicators of fatigue from repeated maximal concentric isokinetic plantar flexion contractions are independent of knee flexion angles and age but differ for males and females. J Strength Cond Res. 2014;28(3):843-55.

${ }^{34}$ Hicks AL, Kent-Braun J, Ditor DS. Sex differences in human skeletal muscle fatigue. Exerc Sport Sci Rev. 2001;29(3):109-12.

Medicine \& Science in Sports \& Exercise, Vol 48, No. 11 (November 2016): pg. 2247-2256. DOI. This article is @ American College of Sports Medicine and permission has been granted for this version to appear in e-Publications@Marquette. American College of Sports Medicine does not grant permission for this article to be further copied/distributed or hosted elsewhere without the express permission from American College of Sports Medicine. 
${ }^{35}$ Hoeger Bement M, Weyer A, Hartley S, Drewek B, Harkins AL, Hunter SK. Pain perception after isometric exercise in women with fibromyalgia. Arch Phys Med Rehabil. 2011;92(1):89-95.

36 Hoeger Bement MK, Dicapo J, Rasiarmos R, Hunter SK. Dose response of isometric contractions on pain perception in healthy adults. Med Sci Sports Exerc. 2008;40(11):1880-9.

37 Hoeger Bement MK, Weyer AD, Yoon T, Hunter SK. Corticomotor excitability during a noxious stimulus before and after exercise in women with fibromyalgia. J Clin Neurophysiol. 2014;31(1):94-8.

38 Hubal MJ, Clarkson PM. Counterpoint: estrogen and sex do not significantly influence post-exercise indexes of muscle damage, inflammation, and repair. J Appl Physiol. 2009;106(3):1012-4; discussion 4, 22.

39 Hunter SK. Sex differences and mechanisms of task-specific muscle fatigue. Exerc Sport Sci Rev. 2009;37(3):113-22.

40 Hunter SK. Sex differences in human fatigability: mechanisms and insight to physiological responses. Acta Physiol (Oxf). 2014;210(4):768-89.

${ }^{41}$ Hunter SK. Sex differences in fatigability of dynamic contractions. Exp Physiol. 2016;101(2):250-5.

42 Hunter SK, Butler JE, Todd G, Gandevia SC, Taylor JL. Supraspinal fatigue does not explain the sex difference in muscle fatigue of maximal contractions. J Appl Physiol (1985). 2006;101(4):1036-44.

43 Hunter SK, Critchlow A, Enoka RM. Influence of aging on sex differences in muscle fatigability. J Appl Physiol (1985). 2004;97(5):1723-32.

${ }^{44}$ Hunter SK, Enoka RM. Sex differences in the fatigability of arm muscles depends on absolute force during isometric contractions. J Appl Physiol (1985). 2001;91(6):2686-94.

45 Hunter SK, Griffith EE, Schlachter KM, Kufahl TD. Sex differences in time to task failure and blood flow for an intermittent isometric fatiguing contraction. Muscle Nerve. 2009;39(1):42-53.

46 Hunter SK, Joyner MJ, Jones AM. The two-hour marathon: what's the equivalent for women? J Appl Physiol (1985). 2015;118(10):1321-3.

47 Hunter SK, Stevens AA. Sex differences in marathon running with advanced age: physiology or participation? Med Sci Sports Exerc. 2013;45(1):148-56.

48 Hunter SK, Stevens AA, Magennis K, Skelton KW, Fauth M. Is there a sex difference in the age of elite marathon runners? Med Sci Sports Exerc. $2011 ; 43(4): 656-64$.

Medicine \& Science in Sports \& Exercise, Vol 48, No. 11 (November 2016): pg. 2247-2256. DOI. This article is @ American College of Sports Medicine and permission has been granted for this version to appear in e-Publications@Marquette. American College of Sports Medicine does not grant permission for this article to be further copied/distributed or hosted elsewhere without the express permission from American College of Sports Medicine. 
NOT THE PUBLISHED VERSION; this is the author's final, peer-reviewed manuscript. The published version may be accessed by following the link in the citation at the bottom of the page.

49 Janse de Jonge XA. Effects of the menstrual cycle on exercise performance. Sports Med. 2003;33(11):833-51.

${ }^{50}$ Kellawan JM, Johansson RE, Harrell JW, et al. Exercise vasodilation is greater in women: contributions of nitric oxide synthase and cyclooxygenase. Eur J Appl Physiol. 2015;115(8):1735-46.

${ }^{51}$ Keller ML, Pruse J, Yoon T, Schlinder-Delap B, Harkins A, Hunter SK. Supraspinal fatigue is similar in men and women for a low-force fatiguing contraction. Med Sci Sports Exerc. 2011;43(10):1873-83.

52 KellerRoss ML, Pereira HM, Pruse J, et al. Stressor-induced increase in muscle fatigability of young men and women is predicted by strength but not voluntary activation. J Appl Physiol (1985). 2014;116(7):76778.

53 Kent-Braun JA, Fitts RH, Christie A. Skeletal muscle fatigue. Compr Physiol. 2012;2(2):997-1044.

${ }^{54}$ Krivickas LS, Fielding RA, Murray A, et al. Sex differences in single muscle fiber power in older adults. Med Sci Sports Exerc. 2006;38(1):57-63.

${ }^{55}$ Krivickas LS, Suh D, Wilkins J, Hughes VA, Roubenoff R, Frontera WR. Age- and gender-related differences in maximum shortening velocity of skeletal muscle fibers. Am J Phys Med Rehabil. 2001;80(6):44755 .

${ }^{56}$ Kuhnen HR, Rybar MM, Onushko T, et al. Stroke-related effects on maximal dynamic hip flexor fatigability and functional implications. Muscle Nerve. 2015;51(3):446-8.

57 Larsson B, Kadi F, Lindvall B, Gerdle B. Surface electromyography and peak torque of repetitive maximum isokinetic plantar flexions in relation to aspects of muscle morphology. J Electromyogr Kinesiol. 2006;16(3):281-90.

58 Laurent CM, Green JM, Bishop PA, et al. Effect of gender on fatigue and recovery following maximal intensity repeated sprint performance. J Sports Med Phys Fitness. 2010;50(3):243-53.

59 Lemley KJ, Hunter SK, Bement MK. Conditioned pain modulation predicts exercise-induced hypoalgesia in healthy adults. Med Sci Sports Exerc. 2015;47(1):176-84.

60 Maher AC, Fu MH, Isfort RJ, Varbanov AR, Qu XA, Tarnopolsky MA. Sex differences in global mRNA content of human skeletal muscle. PLoS One. $2009 ; 4(7):$ e6335.

61 Martin PG, Rattey J. Central fatigue explains sex differences in muscle fatigue and contralateral cross-over effects of maximal contractions. Pflugers Arch. 2007;454(6):957-69.

Medicine \& Science in Sports \& Exercise, Vol 48, No. 11 (November 2016): pg. 2247-2256. DOI. This article is @ American College of Sports Medicine and permission has been granted for this version to appear in e-Publications@Marquette. American College of Sports Medicine does not grant permission for this article to be further copied/distributed or hosted elsewhere without the express permission from American College of Sports Medicine. 
NOT THE PUBLISHED VERSION; this is the author's final, peer-reviewed manuscript. The published version may be accessed by following the link in the citation at the bottom of the page.

62 Martin PG, Weerakkody N, Gandevia SC, Taylor JL. Group III and IV muscle afferents differentially affect the motor cortex and motoneurones in humans. J Physiol. 2008;586(5):1277-89.

63 Maughan RJ, Harmon M, Leiper JB, Sale D, Delman A. Endurance capacity of untrained males and females in isometric and dynamic muscular contractions. Eur J Appl Physiol. 1986;55(4):395-400.

64 Miller AE, MacDougall JD, Tarnopolsky MA, Sale DG. Gender differences in strength and muscle fiber characteristics. Eur J Appl Physiol Occup Physiol. 1993;66(3):254-62.

65 Miller VM. In pursuit of scientific excellence: sex matters. J Appl Physiol. $2012 ; 112(9): 1427-8$.

66 Miller VM. Why are sex and gender important to basic physiology and translational and individualized medicine? Am J Physiol Heart Circ Physiol. 2014;306(6):H781-8.

67 Munn J, Herbert RD, Hancock MJ, Gandevia SC. Resistance training for strength: effect of number of sets and contraction speed. Med Sci Sports Exerc. 2005;37(9):1622-6.

68 Parker BA, Smithmyer SL, Pelberg JA, Mishkin AD, Herr MD, Proctor DN. Sex differences in leg vasodilation during graded knee extensor exercise in young adults. J Appl Physiol (1985). 2007;103(5):158391.

69 Pereira HM, Spears VC, Schlinder-Delap B, et al. Sex differences in arm muscle fatigability with cognitive demand in older adults. Clin Orthop Relat Res. 2015;473(8):2568-77.

70 Pincivero DM, Gandaio CM, Ito Y. Gender-specific knee extensor torque, flexor torque, and muscle fatigue responses during maximal effort contractions. Eur J Appl Physiol. 2003;89(2):134-41.

71 Porter MM, Stuart S, Boij M, Lexell J. Capillary supply of the tibialis anterior muscle in young, healthy, and moderately active men and women. J Appl Physiol (1985). 2002;92(4):1451-7.

72 Power GA, Dalton BH, Rice CL, Vandervoort AA. Delayed recovery of velocity-dependent power loss following eccentric actions of the ankle dorsiflexors. J Appl Physiol. 2010;109(3):669-76.

73 Power GA, Dalton BH, Rice CL, Vandervoort AA. Peak power is reduced following lengthening contractions despite a maintenance of shortening velocity. Appl Physiol Nutr Metab. 2013;38(12):1196-205.

74 Prendergast BJ, Onishi KG, Zucker I. Female mice liberated for inclusion in neuroscience and biomedical research. Neurosci Biobehav Rev. $2014 ; 40: 1-5$.

Medicine \& Science in Sports \& Exercise, Vol 48, No. 11 (November 2016): pg. 2247-2256. DOI. This article is @ American College of Sports Medicine and permission has been granted for this version to appear in e-Publications@Marquette. American College of Sports Medicine does not grant permission for this article to be further copied/distributed or hosted elsewhere without the express permission from American College of Sports Medicine. 
NOT THE PUBLISHED VERSION; this is the author's final, peer-reviewed manuscript. The published version may be accessed by following the link in the citation at the bottom of the page.

${ }^{75}$ Qaisar R, Renaud G, Hedstrom Y, et al. Hormone replacement therapy improves contractile function and myonuclear organization of single muscle fibres from postmenopausal monozygotic female twin pairs. J Physiol. 2013;591(Pt 9):2333-44.

76 Racine M, Tousignant-Laflamme Y, Kloda LA, Dion D, Dupuis G, Choiniere M. A systematic literature review of 10 years of research on sex/gender and experimental pain perception: part 1 . Are there really differences between women and men? Pain. 2012;153(3):602-18.

77 Rinard J, Clarkson PM, Smith LL, Grossman M. Response of males and females to high-force eccentric exercise. J Sports Sci. $2000 ; 18(4): 229-36$.

78 Roepstorff C, Thiele M, Hillig T, et al. Higher skeletal muscle alpha2AMPK activation and lower energy charge and fat oxidation in men than in women during submaximal exercise. J Physiol. 2006;574(Pt 1):12538.

79 Roig M, O'Brien K, Kirk G, et al. The effects of eccentric versus concentric resistance training on muscle strength and mass in healthy adults: a systematic review with meta-analysis. $\mathrm{Br}$ J Sports Med. 2009;43(8):556-68.

80 Ronkainen PH, Kovanen V, Alen M, et al. Postmenopausal hormone replacement therapy modifies skeletal muscle composition and function: a study with monozygotic twin pairs. J Appl Physiol. $2009 ; 107(1): 25-33$.

81 Russ DW, Kent-Braun JA. Sex differences in human skeletal muscle fatigue are eliminated under ischemic conditions. J Appl Physiol (1985). 2003;94(6):2414-22.

82 Russ DW, Lanza IR, Rothman D, Kent-Braun JA. Sex differences in glycolysis during brief, intense isometric contractions. Muscle Nerve. 2005;32(5):647-55.

83 Senefeld J, Yoon T, Bement MH, Hunter SK. Fatigue and recovery from dynamic contractions in men and women differ for arm and leg muscles. Muscle Nerve. 2013;48(3):436-9.

84 Sewright KA, Hubal MJ, Kearns A, Holbrook MT, Clarkson PM. Sex differences in response to maximal eccentric exercise. Med Sci Sports Exerc. 2008;40(2):242-51.

85 Simoneau JA, Bouchard C. Human variation in skeletal muscle fiber-type proportion and enzyme activities. Am J Physiol. 1989;257:E567-72.

${ }^{86}$ Simoneau JA, Lortie G, Boulay MR, Thibault MC, Theriault G, Bouchard C. Skeletal muscle histochemical and biochemical characteristics in

Medicine \& Science in Sports \& Exercise, Vol 48, No. 11 (November 2016): pg. 2247-2256. DOI. This article is @ American College of Sports Medicine and permission has been granted for this version to appear in e-Publications@Marquette. American College of Sports Medicine does not grant permission for this article to be further copied/distributed or hosted elsewhere without the express permission from American College of Sports Medicine. 
NOT THE PUBLISHED VERSION; this is the author's final, peer-reviewed manuscript. The published version may be accessed by following the link in the citation at the bottom of the page.

sedentary male and female subjects. Can J Physiol Pharmacol. $1985 ; 63(1): 30-5$.

87 Skurvydas A, Brazaitis M, Andrejeva J, Mickeviciene D, Streckis V. The effect of multiple sclerosis and gender on central and peripheral fatigue during 2-min MVC. Clin Neurophysiol. 2011;122(4):767-76.

88 Staron RS, Hagerman FC, Hikida RS, et al. Fiber type composition of the vastus lateralis muscle of young men and women. J Histochem Cytochem. 2000;48(5):623-9.

89 Tarnopolsky MA. Sex differences in exercise metabolism and the role of 17-beta estradiol. Med Sci Sports Exerc. 2008;40(4):648-54.

90 Temesi J, Arnal PJ, Rupp T, et al. Are Females More Resistant to Extreme Neuromuscular Fatigue? Med Sci Sports Exerc. 2015;47(7):1372-82.

91 Toft I, Lindal S, Bonaa KH, Jenssen T. Quantitative measurement of muscle fiber composition in a normal population. Muscle Nerve. $2003 ; 28(1): 101-8$.

92 Trappe S, Gallagher P, Harber M, Carrithers J, Fluckey J, Trappe T. Single muscle fibre contractile properties in young and old men and women. J Physiol. 2003;552(Pt 1):47-58.

93 Vanden Noven ML, Pereira HM, Yoon T, Stevens AA, Nielson KA, Hunter SK. Motor variability during sustained contractions increases with cognitive demand in older adults. Front Aging Neurosci. 2014;6:97.

94 Wizemann T, Pardue M. Exploring the Biological Contributions to Human Health: Does Sex Matter? Board on Health Sciences Policy. Institute of Medicine. Washington (DC): National Academy Press; 2001.

95 Wust RC, Morse CI, de Haan A, Jones DA, Degens H. Sex differences in contractile properties and fatigue resistance of human skeletal muscle. Exp Physiol. 2008;93(7):843-50.

96 Yoon T, Doyel R, Widule C, Hunter SK. Sex differences with aging in the fatigability of dynamic contractions. Exp Gerontol. 2015;70:1-10.

97 Yoon T, Keller ML, De-Lap BS, Harkins A, Lepers R, Hunter SK. Sex differences in response to cognitive stress during a fatiguing contraction. J Appl Physiol (1985). 2009;107(5):1486-96.

98 Yoon T, Schlinder Delap B, Griffith EE, Hunter SK. Mechanisms of fatigue differ after low- and high-force fatiguing contractions in men and women. Muscle Nerve. 2007;36:512-24.

99 Yoon T, Vanden Noven ML, Nielson KA, Hunter SK. Brain areas associated with force steadiness and intensity during isometric ankle dorsiflexion in men and women. Exp Brain Res. 2014;232(10):3133-45.

Medicine \& Science in Sports \& Exercise, Vol 48, No. 11 (November 2016): pg. 2247-2256. DOI. This article is @ American College of Sports Medicine and permission has been granted for this version to appear in e-Publications@Marquette. American College of Sports Medicine does not grant permission for this article to be further copied/distributed or hosted elsewhere without the express permission from American College of Sports Medicine. 
NOT THE PUBLISHED VERSION; this is the author's final, peer-reviewed manuscript. The published version may be accessed by following the link in the citation at the bottom of the page.

100 Zhang Z, Li KW, Zhang W, Ma L, Chen Z. Muscular fatigue and maximum endurance time assessment for male and female industrial workers. Int J Ind Ergon. 2014;44(2):292-7.

Medicine \& Science in Sports \& Exercise, Vol 48, No. 11 (November 2016): pg. 2247-2256. DOI. This article is (C) American College of Sports Medicine and permission has been granted for this version to appear in e-Publications@Marquette. American College of Sports Medicine does not grant permission for this article to be further copied/distributed or hosted elsewhere without the express permission from American College of Sports Medicine. 